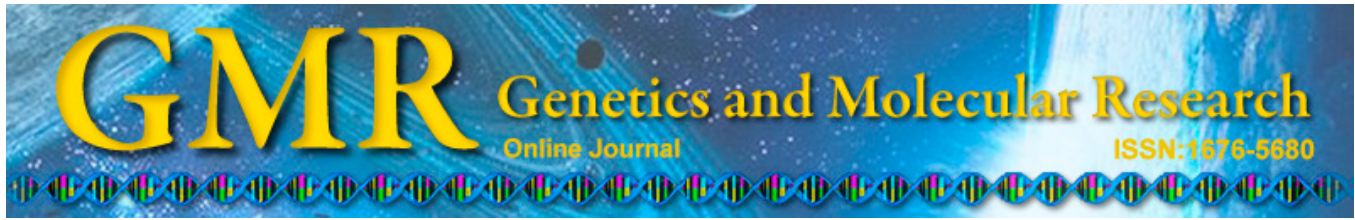

\title{
Association between interleukin gene polymorphisms and risk of recurrent oral ulceration
}

C. Jing and J.-Q. Zhang

Department of Stomatology,

The First Affiliated Hospital of PLA General Hospital, Beijing, China

Corresponding author: J.-Q. Zhang

E-mail: zhangjianqiang54@163.com

Genet. Mol. Res. 14 (2): 6838-6843 (2015)

Received September 17, 2014

Accepted March 6, 2015

Published June 18, 2015

DOI http://dx.doi.org/10.4238/2015.June.18.26

\begin{abstract}
We conducted a case-control study to investigate the association between the functional IL-1 $\beta+3954$ (C/T), IL-6-174 (G/C), IL-10-1082 (G/A), and IL-10-819C/T genetic polymorphisms and risk of recurrent oral ulceration (ROU) in a Chinese population. Polymorphisms of IL-1 $\beta+3954 \mathrm{C} / \mathrm{T}$, IL-6-174G/C, IL-10-1082A/G and IL-10-819C/T were assessed by polymerase chain reaction-restriction fragment length polymorphism. The genotype distributions of the IL$1 \beta+3954 \mathrm{C} / \mathrm{T}$ and IL-10-819C/T were in Hardy-Weinberg equilibrium in the control group. Conditional logistic regression analyses showed that subjects carrying the IL- $1 \beta+3954 \mathrm{CC}$ and IL-10-1082AA genotypes had a significantly increased risk of ROU, with adjusted ORs $(95 \% \mathrm{CI})$ of 2.86 (1.37-6.33) and 1.72 (1.02-2.89), respectively. In summary, we found that IL-1 $\beta+3954 \mathrm{C} / \mathrm{T}$ and IL-10-1082A/G polymorphisms are associated with an increased risk of ROU.
\end{abstract}

Key words: Recurrent oral ulceration; Interleukin gene; Polymorphism 


\section{INTRODUCTION}

Recurrent oral ulceration (ROU) is known as recurrent aphthous stomatitis, which is characterized by recurrent episodes of oral ulcers in healthy individuals and affects about $20 \%$ of populations (Stanley, 1972; Porter et al., 1998). It is well known that ROU has multi-factor causes, including both genetic and environmental factors. Family history of ROU is confirmed to be a risk factor for ROU (Natah et al., 2004). It has been reported that psychological factors can also influence the pathologic process of ROU (McCartan et al., 1996; Natah et al., 2004), and a previous study reported that serotonin transporter gene polymorphism (5-HTTLPR) is associated with anxiety-related traits (McCartan et al., 1996; Natah et al., 2004; Victoria et al., 2005).

Since the etiology of ROU is not well understood, previous studies reported that inflammatory factors play an important role in the development of ROU (Sun et al., 2013; Najafi et al., 2014). A previous study reported that cytokine genes in peripheral blood mononuclear cells were associated with disease development in ROU patients, such as IL-2, TNF- $\alpha$ and IL-6 (Borra et al., 2004). Moreover, decreased IL-10 mRNA levels were found in ROU patients, which suggests a failure of the immune system to suppress inflammatory reaction to oral mucosa (Lewkowicz et al., 2005).

Up to now, there are no reported studies on the association between inflammatory genes and risk of ROU. Therefore, considering the immunological alterations in the pathogenesis of ROU, we conducted a case-control study to investigate the association between the functional IL-1 $\beta+3954$ C/T (rs1143634), IL-6-174G/C (rs1800795), IL-10-1082A/G (rs1800896), and IL$10-819 \mathrm{C} / \mathrm{T}$ (rs1800871) genetic polymorphisms and risk of ROU in a Chinese population.

\section{MATERIAL AND METHODS}

\section{Patients}

A total of 264 consecutive patients with ROU were enrolled in the study, and they were diagnosed by a dentist. The diagnostic criteria were horizontal range being covered with yellow pseudomembrane, surrounding hyperemia, with central sag and obvious causalgia, being at different ictal phase, having cyclicity and being self-limiting. For the control group, 176 subjects without ROU were recruited from the individuals getting a routine check-up in the health examination center. The subjects in the control group had no history of ROU. The control subjects were matched with the cases by sex and age.

There were 117 males and 147 females in the case and control groups, and the age of case and control groups ranged from 19 to 74 years old. Informed consent was obtained from all cases and control subjects or their relatives before being enrolling in this study. The protocol of this study was approved by the Ethics Committee of the First Affiliated Hospital of PLA General Hospital.

\section{DNA isolation}

Each case and control was asked to provide $5 \mathrm{~mL}$ blood for DNA sequencing after agreeing to participate in our study. The IL-1 $\beta$, IL- 6 and IL-10 polymorphisms were analyzed using genomic DNA purified from peripheral blood. All study participants provided $5 \mathrm{~mL}$ venous blood, and their blood samples were kept at $-20^{\circ} \mathrm{C}$ until use, where $0.5 \mathrm{mg} / \mathrm{mL}$ ethyl- 
enediaminetetraacetic acid was used as the anticoagulant. Genomic DNA was isolated from peripheral blood leukocytes using the TIANamp Blood DNA kit (Tiangen, Beijing, China) according to the manufacturer instructions, and genomic DNA was stored at $-20^{\circ} \mathrm{C}$ until use.

\section{Determination of IL-1 $\beta$, IL-8 and IL-10 polymorphisms}

Polymorphisms of IL-1 $\beta+3954 \mathrm{C} / \mathrm{T}$, IL-6-174G/C, IL-10-1082A/G, and IL-10-819C/Twere assessed by polymerase chain reaction-restriction fragment length polymorphism (PCR-RFLP). Primers of IL-1 $\beta+3954 C / T$ (rs1143634), IL-6-174G/C (rs1800795), IL-10-1082A/G (rs1800896), and IL-10-819C/T (rs1800871) were designed using the Sequenom Assay Design 3.1 software, and are shown in Table 1. PCR was performed in a $50-\mu \mathrm{L}$ reaction mixture containing $25 \mathrm{mM} \mathrm{MgCl}, 2$ $\mathrm{mM}$ dNTPs, $20 \mu \mathrm{M}$ primer, and $5 \mathrm{U} / \mu \mathrm{L}$ Taq DNA. PCR was performed using the following conditions: initial denaturation at $94^{\circ} \mathrm{C}$ for $5 \mathrm{~min}$, followed by 35 cycles of denaturation at $94^{\circ} \mathrm{C}$ for $45 \mathrm{~s}$, annealing at $62^{\circ} \mathrm{C}$ for $60 \mathrm{~s}$ and extension at $72^{\circ} \mathrm{C}$ for $60 \mathrm{~s}$, and final extension at $72^{\circ} \mathrm{C}$ for $10 \mathrm{~min}$. The PCR products were visualized by $1.0 \%$ agarose gel electrophoresis with ethidium bromide staining and UV light. For quality control, a randomly chosen group of $10 \%$ of cases and control subjects were selected, and the results of repeated samples showed $100 \%$ concordance.

Table 1. Primer sequences and restriction enzymes for each polymorphism.

\begin{tabular}{lll}
\hline Genes & Primers & Restriction enzyme \\
\hline IL-1 $\beta+3954 \mathrm{C} / \mathrm{T}$ & GCCTGCCCTTCTGATTTTATACC & TaqI \\
$\mathrm{IL}-6-174 \mathrm{G} / \mathrm{C}$ & CATCGTGCACATAAGCCTCGTTA & Hsp $92 \mathrm{II}$ \\
$\mathrm{IL}-10-1082 \mathrm{~A} / \mathrm{G}$ & CAGAAGAACTCAGATGACCTG & XagI \\
$\mathrm{IL}-10-819 \mathrm{C} / \mathrm{T}$ & GTGGGGCTGATTGGAACC & HinI $a$ \\
& CCAAGACAACACTACTAAGGCTCCTTT & \\
\hline
\end{tabular}

\section{Statistical analysis}

Continuous variables are reported as means \pm standard deviation (SD), and categorical variables are reported as N (\%) of study participants. The Student $t$-test was used to compare continuous variables between patients and control subjects, and $\chi^{2}$-test was used to compare categorical variables between patients and control subjects. Hardy-Weinberg equilibrium among controls was compared using the $\chi^{2}$-test. Unconditional logistic regression was conducted to assess the effects of the IL-1 $\beta$, IL-6 and IL-10 polymorphisms on the risk of ROU, with results expressed as odds ratios (OR) and corresponding 95\% confidence intervals (CIs) on risk of ROU. Homozygotes of the most frequent genotype were regarded as the reference group. All P values were two sided, and $\mathrm{P}<0.05$ was considered as statistically significant. All statistical analyses were conducted using SPSS $^{\circledR}$ statistical package, version 11.0 (SPSS Inc., Chicago, IL, USA) for Windows ${ }^{\circledR}$.

\section{RESULTS}

The demographic and clinical characteristics of study subjects are shown in Table 2. Of the 264 patients with ROU, 117 subjects (44.32\%) were males and 147 (55.68\%) were females. The mean age of patients and controls were respectively $51.6 \pm 11.3$ and $35.4 \pm 16.8$ years old. A total of 166 patients $(37.12 \%)$ had 3 or more lesions of ROU, and 64 (24.24\%) 
had ROU on floor of the mouth, 89 (33.71\%) on lips, 80 (30.30\%) on oral mucosa, 25(9.47\%) on tongue, and $6(2.27 \%)$ on soft palate.

The genotype distributions of the IL-6-174G/C and IL-10-1082A/G were in HardyWeinberg equilibrium in the control group (Table 3). However, genotype distributions of IL$1 \beta+3954 \mathrm{C} / \mathrm{T}$ and IL-10-819C/T were not. Moreover, we found that minor allele frequencies of the five gene polymorphisms in the control group were similar to that in dbSNP.

Conditional logistic regression analyses showed that subjects carrying the IL$1 \beta+3954 \mathrm{CC}$ genotype were significantly associated with increased risk of ROU, with adjusted ORs (95\%CI) of 2.86 (1.37-6.33) (Table 4). Moreover, we found that IL-10-1082AA genotype can increase the risk of ROU when compared with GG genotype, and that the OR $(95 \% \mathrm{CI})$ was $1.72(1.02-2.89)$. However, we did not observe a significant association between IL-6$174 \mathrm{G} / \mathrm{C}$ and IL-10-819C/T polymorphisms and risk of ROU.

Table 2. Characteristics of ROU patients and controls.

\begin{tabular}{|c|c|c|c|c|c|c|}
\hline Characteristics & Cases & $\%$ & Controls & $\%$ & $\chi^{2}$ or $t$ & $\mathrm{P}$ value \\
\hline Mean age (range of years) & $35.4 \pm 16.8$ & & $36.2 \pm 16.5$ & & 0.55 & 0.29 \\
\hline \multicolumn{7}{|l|}{ Gender } \\
\hline Male & 117 & 44.32 & 117 & 44.32 & 0.00 & 1.00 \\
\hline Female & 147 & 55.68 & 147 & 55.68 & & \\
\hline \multicolumn{7}{|l|}{ Number of lesions of ROU } \\
\hline$<3$ lesions & 166 & 62.88 & & & & \\
\hline$\geq 3$ lesion & 98 & 37.12 & & & & \\
\hline \multicolumn{7}{|l|}{ Sites of ROU } \\
\hline Floor of the mouth & 64 & 24.24 & & & & \\
\hline Lips & 89 & 33.71 & & & & \\
\hline Buccal mucosa & 80 & 30.30 & & & & \\
\hline Tongue & 25 & 9.47 & & & & \\
\hline Soft palate & 6 & 2.27 & & & & \\
\hline
\end{tabular}

Table 3. Genotype characteristics of the four SNPs in the cases and controls.

\begin{tabular}{|c|c|c|c|c|c|}
\hline \multirow[t]{2}{*}{ Gene } & \multirow[t]{2}{*}{ SNP } & \multirow[t]{2}{*}{ Alleles } & \multicolumn{2}{|c|}{$\mathrm{MAF}^{1}$} & \multirow[t]{2}{*}{$\mathrm{HWE}^{2}$ ( $\mathrm{P}$ value) in controls } \\
\hline & & & Control group & From dbSNP & \\
\hline IL-1 $\beta+3954 \mathrm{C} / \mathrm{T}$ & rs1143634 & $\mathrm{C} / \mathrm{T}$ & 0.165 & 0.146 & 0.025 \\
\hline IL-6-174G/C & rs1800795 & $\mathrm{G} / \mathrm{C}$ & 0.207 & 0.185 & 0.63 \\
\hline IL-10-1082A/G & rs 1800896 & $\mathrm{~A} / \mathrm{G}$ & 0.329 & 0.303 & 0.01 \\
\hline IL-10-819C/T & rs 1800871 & $\mathrm{C} / \mathrm{T}$ & 0.409 & 0.409 & 0.08 \\
\hline
\end{tabular}

${ }^{1}$ MAF: minor allele frequencies; ${ }^{2} \mathrm{HWE}$ : Hardy-Weinberg equilibrium.

Table 4. Association between four SNPs and risk of ROU.

\begin{tabular}{|c|c|c|c|c|c|c|c|}
\hline SNPs & & Cases $(\mathrm{N}=264)$ & $\%$ & Controls $(\mathrm{N}=264)$ & $\%$ & Adjusted OR $(95 \% \mathrm{CI})^{1}$ & $\mathrm{P}$ value \\
\hline \multirow[t]{3}{*}{$\mathrm{IL}-1 \beta+3954 \mathrm{C} / \mathrm{T}$} & $\mathrm{CC}$ & 165 & 62.4 & 189 & 71.7 & 1.0 (Ref.) & - \\
\hline & CT & 69 & 26.2 & 62 & 23.6 & $1.27(0.84-1.94)$ & 0.24 \\
\hline & TT & 30 & 11.4 & 12 & 4.7 & $2.86(1.37-6.33)$ & 0.002 \\
\hline \multirow[t]{3}{*}{ IL-6-174G/C } & TT & 151 & 57.2 & 165 & 62.4 & 1.0 (Ref.) & - \\
\hline & TA & 95 & 35.9 & 89 & 33.8 & $1.17(0.80-1.71)$ & 0.41 \\
\hline & AA & 18 & 6.9 & 10 & 3.8 & $1.97(0.83-4.92)$ & 0.09 \\
\hline \multirow[t]{3}{*}{ IL-10-1082A/G } & AA & 106 & 40.2 & 128 & 48.5 & 1.0 (Ref.) & - \\
\hline & $\mathrm{AG}$ & 104 & 39.5 & 98 & 37.2 & $1.28(0.86-1.90)$ & 0.2 \\
\hline & GG & 54 & 20.3 & 38 & 14.3 & $1.72(1.02-2.89)$ & 0.03 \\
\hline \multirow[t]{3}{*}{ IL-10-819C/T } & $\mathrm{CC}$ & 89 & 33.6 & 99 & 37.5 & 1.0 (Ref.) & - \\
\hline & CT & 119 & 45.2 & 114 & 43.18 & $1.16(0.78-1.74)$ & 0.45 \\
\hline & TT & 56 & 21.2 & 51 & 19.32 & $1.22(0.74-2.02)$ & 0.41 \\
\hline
\end{tabular}

${ }^{1}$ Adjusted for gender and age. 


\section{DISCUSSION}

ROU is a common oral disease, and the etiology of ROU is not well understood. Previous studies reported that many factors play an important role in the development of ROU, including immunological, psychological, genetic and microbiological factors (Natah et al., 2004; Jurge, 2006). Our study showed that IL-1 $\beta+3954$ C/T and IL-10-1082A/G polymorphism may increase the risk of ROU.

Previous studies have shown that polymorphisms of cytokines have been associated with risk of oral mucosal disease (Bazrafshani et al., 2002; Bai et al., 2007; Xavier et al., 2007; Guimarães et al., 2007a; Kalkan et al., 2013). Kalkan et al. (2013) reported that intron 3 VNTR polymorphism in the IL-4 gene plays an important role in the development of recurrent aphthous stomatitis in the Turkish population. Bai et al. (2007) conducted a cohort study in a Chinese cohort, and reported that IL-18 polymorphism is associated with pathogenesis of oral lichen planus. Xavier et al. (2007) reported that IL- 6 and TNF- $\alpha$ gene polymorphisms are associated with occurrence of oral lichen planus. For ROU, Guimarães et al. (2007a) reported that polymorphism of high IL-1 $\beta$ production was correlated with an increased risk of ROU. IL-6 gene polymorphisms can increase susceptibility to ROU (Bazrafshani et al., 2002). Our study showed that IL-1 $\beta+3954$ CC and IL-10-1082AA genotypes were significantly associated with increased risk of ROU. Two studies reported similar results. Bazrafshani et al. (2003) reported that IL-10 and IL-12 gene polymorphisms can influence susceptibility to ROU. Guimarães et al. (2007b) showed that polymorphism of IL- $1 \beta+3954 \mathrm{C} / \mathrm{T}$ is correlated with an increased risk of ROU development. However, another study reported inconsistent results with ours. Sun et al. (2013) reported no association between IL-10 polymorphism and development of ROU. Discrepancies in ethnicity, sample size, control selection and study design can cause the difference between results of studies. Further studies are greatly needed to clarify the association between IL-1 $\beta$ and IL-10 polymorphisms and risk of ROU.

There were two limitations in our study. First, a relatively small sample size would limit the statistical power to find the difference between groups. Second, genotype distributions of IL-1 $\beta+3954 \mathrm{C} / \mathrm{T}$ and IL-10-1082A/G were not in Hardy-Weinberg equilibrium in the control group, which showed that the control could not represent well the distribution of the general population. Therefore, selection bias may exist in our study. Third, other genetic polymorphisms may greatly influence the risk of ROU, besides the inflammatory cytokines. Therefore, further well-designed, large sample and multicenter studies are greatly needed to investigate the association between inflammatory cytokines and risk of ROU.

In summary, we found that IL- $1 \beta+3954 \mathrm{C} / \mathrm{T}$ and IL-10-1082A/G polymorphisms are associated with an increased risk of ROU, and that no significant association exists between IL-6-174G/C and IL-10-819C/T gene polymorphisms and risk of ROU. Due to the limitations of our study, further well-designed, large sample and multicenter studies are greatly needed.

\section{REFERENCES}

Bai J, Zhang Y, Lin M, Zeng X, et al. (2007). Interleukin-18 gene polymorphisms and haplotypes in patients with oral lichen planus: a study in an ethnic Chinese cohort. Tissue Antigens. 70: 390-397.

Bazrafshani MR, Hajeer AH, Ollier W and Thornhill MH. (2002). IL-1B and IL-6 gene polymorphisms encode significant risk for the development of recurrent aphthous stomatitis (RAS). Genes Immun 3: 302-305.

Bazrafshani MR, Hajeer AH, Ollier WE and Thornhill MH. (2003). Polymorphisms in the IL-10 and IL-12 gene cluster and risk of developing recurrent aphthous stomatitis. Oral Dis. 9: 287-291. 
Borra RC, Andrade PM, Silva ID, Morgun A, et al. (2004). The Th1/Th2 immunetype response of the recurrent aphthous ulceration analyzed by cDNA microarray. J. Oral Pathol. Med. 33: 140-146.

Guimarães AL, Correia-Silva JF, Diniz MG, Xavier GM, et al. (2007a). Investigation of functional gene polymorphisms: IL-1B, IL-6 and TNFA in benign migratory glossitis in Brazilian individuals. J. Oral Pathol. Med. 36: 533-537.

Guimarães AL, Correia-Silva Jde F, Sá AR, Victória JM, et al. (2007b). Investigation of functional gene polymorphisms IL-1beta, IL-6, IL-10 and TNF-alpha in individuals with recurrent aphthous stomatitis. Arch Oral Biol. 52: 268-272.

Jurge S, Kuffer R, Scully C and Porter SR (2006). Mucosal disease series. Number VI. Recurrent aphthous stomatitis. Oral Dis. 12: 1-21.

Kalkan G, Yigit S, Karakus N, Baş Y, et al. (2013). Association between interleukin 4 gene intron 3 VNTR polymorphism and recurrent aphthous stomatitis in a cohort of Turkish patients. Gene. 527: 207-210.

Lewkowicz N, Lewkowicz P, Banasik M, Kurnatowska A, et al. (2005). Predominance of Type 1 cytokines and decreased number of CD4(+)CD25(+high) T regulatory cells in peripheral blood of patients with recurrent aphthous ulcerations. Immunol Lett 99: 57-62.

McCartan BE, Lamey PJ and Wallace AM (1996). Salivary cortisol and anxiety in recurrent aphthous stomatitis. J. Oral Pathol. Med. 25: 357-359.

Najafi S, Firooze Moqadam I, Mohammadzadeh M, Bidoki AZ, et al. (2014). Interleukin-10 gene polymorphisms in recurrent aphthous stomatitis. Immunol Invest. 43: 405-409.

Natah SS, Konttinen YT, Enattah NS, Ashammakhi N, et al. (2004) Recurrent aphthous ulcers today: a review of the growing knowledge. Int. J. Oral Maxillofac Surg. 33: 221-234.

Stanley HR (1972). Aphthous lesions. Oral Surg. Oral Med. Oral Pathol. 33: 407-416.

Sun M, Fu SM, Dong GY, Wu D, et al. (2013). Inflammatory factors gene polymorphism in recurrent oral ulceration. $J$. Oral Pathol. Med. 42: 528-534.

Porter SR, Scully C and Pedersen A. (1998). Recurrent aphthous stomatitis. Crit. Rev. Oral Biol. Med. 9: 306-321.

Victoria JM, Correia-Silva JF, Pimenta FJ, Kalapothakis E, et al. (2005). Serotonin transporter gene polymorphism (5HTTLPR) in patients with recurrent aphthous stomatitis. J. Oral Pathol. Med. 34: 494-497.

Xavier GM, de Sá AR, Guimarães AL, da Silva TA, et al. (2007). Investigation of functional gene polymorphisms interleukin-1beta, interleukin-6, interleukin-10 and tumor necrosis factor in individuals with oral lichen planus. $J$. Oral Pathol. Med. 36: 476-481. 